\title{
Evaluation of Seven Sorghums, Selfed and Crossed to Three Cytoplasmic Male-Sterile Lines $^{1}$
}

\author{
A. Sotomayor-Ríos and D. E. Weibel ${ }^{2}$
}

\begin{abstract}
Seven grain sorghum lines (Sorghum bicolor (L.) Moench) selected from the Sorghum Conversion Program (SCP) and their $F_{1}$ hybrids from crosses with CK-60, Martin, and Redlan were evaluated. Days to midflower, height, rust (Puccinia purpurea Ckd.) reaction, number of heads/plot, test weight, threshing percentage, and grain yield were rated or measured. The seven lines when selfed were, in general, the latest to reach midflower. Four height groups were observed; the taller hybrids were the result of the complementary effect of different height factors in the parents. Rust ratings ranged from 2.9 to $4.9 ; F_{1}$ hybrids Martin $\times 4$, Martin $\times 7$, and Redlan $\times 7$ were the most susceptible to rust. Generally, sorghums with a high grain yield also had a high test weight and threshing percentage. The grain yield ranged from 1,866 to $4,261 \mathrm{~kg} / \mathrm{ha}$. Mean yields were, on the average, $26 \%$ higher for $F_{1}$ hybrids than for their respective male parents. A $67 \%$ heterosis for grain yield was observed in two crosses involving Martin and Redlan female parents.
\end{abstract}

\section{INTRODUCTION}

The Sorghum Conversion Program (SCP) is an excellent channel through which selected tropical types are made available to breeding programs in the temperate climates (3). This program involves a series of crosses and backcrosses in Puerto Rico and careful selections in Texas for the final conversion of tropical to temperate sorghum types $(1,5)$. The SCP is changing the sorghum breeding patterns in the temperate and tropical zones by providing material for improvement of such properties as disease and insect resistance, drought tolerance, sterility, grain quality, and many others. Schertz (3) listed 12 improvements that are possible through the SCP, one of the most important being the reduction of genetic vulnerability to diseases by use of new cytoplasmic-genetic sterility systems.

The purpose of this study was to compare seven lines from the SCP and their $F_{1}$ hybrids from crosses with three male-sterile lines, all grown under short-day conditions in Puerto Rico, for grain yield, rust resistance, and a series of morphological characters.

\section{MATERIALS AND METHODS}

The experiment was conducted at the Isabela experiment farm of the Mayagüez Institute of Tropical Agriculture (MITA), ARS, USDA,

1 Manuscript submitted to Editorial Board May 17, 1977.

${ }^{2}$ Research Geneticist, Mayagüez Institute of Tropical Agriculture, ARS, USDA, Mayagüez, P.R. 00708, and Professor of Agronomy, Oklahoma Agricultural Experiment Station, Oklahoma State University, Stillwater. Ok. 74074, respectively. The help of Dr. Rodrigo Alconero in evaluating plants for rust ratings is deeply appreciated. 
which is located about $128 \mathrm{~m}$ above sea level and has temperatures ranging from $18^{\circ}$ to $31^{\circ} \mathrm{C}$. The soil is Coto clay (an Oxisol) with a $\mathrm{pH}$ of about 5.5. Before planting, a complete fertilizer (15-5-10) was applied to all plots at about $448 \mathrm{~kg} / \mathrm{ha}$.

Seven grain sorghum lines selected from the Conversion Program were crossed with three cytoplasmic male-sterile lines (CK-60, Martin, and Redlan) to produce $21 \mathrm{~F}_{1}$ hybrids, which were compared with the same seven lines, selfed. The description and origin of these seven lines were reported in a previous paper by Sotomayor-Ríos and Miller (4). The experimental design was randomized complete blocks with six replications. Each plot consisted of two rows spaced $101 \mathrm{~cm}$ apart about $6 \mathrm{~m}$ long. A $6-\mathrm{m}^{2}$ area of each plot was used for grain-yield sampling.

Methiocarb [4-(methylthio)-3,5-xylyl methylcarbamate] (Mesurol) ${ }^{3}$ was applied to sorghum heads at about $3 \mathrm{~kg} / \mathrm{ha}$ at the initiation of the grain filling period as a bird repellent.

The following data were collected: 1) Number of days from planting to midflower (visual estimate); 2) height of plants (from the ground to the tip of the head), average for 5 plants/plot; 3) rust (Puccinia purpurea $\mathrm{Ckd}$.) rating ( $1=$ trace to $25 \%$ infection of leaf blades; $2=$ $26-50 \% ; 3=51-75 \% ; 4=76-100 \%$; and $5=$ at least half of leaf blades dying or dead, and pustules on stems, visual estimate); 4) number of heads/6- $\mathrm{m}^{2}$ plot $(\mathrm{H} / \mathrm{p}) ; 5$ ) test weight (TW), determined with a container , of known volume and expressed in $\mathrm{kg} / \mathrm{hl} ; 6$ ) threshing percentage (TP) (weight of threshed grain $\times 100 /$ weight of unthreshed grain), determined on the yield sample; 7) grain yield (GY) at $14 \%$ moisture, determined from the harvested $6-\mathrm{m}^{2}$ plot; and 8) heterosis $(\%)=$ hybrid - parent

parent

\section{RESULTS AND DISCUSSION}

Table 1 shows the means for number of days from planting to midflower, height, rust rating, H/p, TW, TP, and GY of the seven lines selfed and their $F_{1}$ hybrids. The mean effects of the male and female parents on these traits are shown in table 2. These traits in the seven lines selfed and in their best or highest value $\mathrm{F}_{1}$ hybrids are compared in table 3.

Days to midflower for all selfed lines and hybrids ranged from 56.3 to 67.8 days (table 1). All male-parental lines reached midflower later than any of their $\mathrm{F}_{1}$ hybrids. Redlan hybrids were earlier than Martin

${ }^{3}$ Trade names are used in this publication solely for the purpose of providing specific information. Mention of a trade isame does not constitute a guarantee or warranty of equipment or materials by the Agricultural Experiment Station of the University of Puerto Rico or an endorsement over other equipment or materials not mentioned. 
TABLE 1. - Means for number of days from planting to midflower, height, rust rating, heads/plot, (H/p), test weight (TW), threshing percentage (TP), and grain yield $(G Y)$ of seven sorghum lines and their $F_{1}$ hybrids from crosses with three cytoplasmic male-sterile lines (CK - 60, Martin, and Redlan), all grown at Isabela, P.R.

\begin{tabular}{|c|c|c|c|c|c|c|c|}
\hline Line or hybrid & $\begin{array}{l}\text { Days to } \\
\text { midflower }\end{array}$ & Height & Rust rating & $\mathrm{H} / \mathrm{P}$ & TW & $\mathrm{TP}$ & GY \\
\hline & & $\mathrm{Cm}$ & & & $K g / h l$ & & $K g / h a$ \\
\hline 4 & $64.0 c^{1}$ & $131.7 \mathrm{f}$ & $4.3 \mathrm{~b}$ & $52.0 \mathrm{fgh}$ & $72.3 \mathrm{~g}$ & $67.0 \mathrm{k}$ & $1,951 \mathrm{j}$ \\
\hline 5 & $67.8 \mathrm{a}$ & $81.0 \mathrm{~h}$ & $3.0 \mathrm{fg}$ & $49.7 \mathrm{~h}$ & 76.3 ef & $70.7 \mathrm{ijk}$ & $2,100 \mathrm{j}$ \\
\hline 6 & $66.0 \mathrm{~b}$ & $127.7 \mathrm{f}$ & $2.9 \mathrm{~g}$ & 56.2 bcdefgh & 78.5 abcde & 75.8 defg & 3,006 ghi \\
\hline 7 & $64.7 \mathrm{bc}$ & $127.2 \mathrm{f}$ & $4.1 \mathrm{bc}$ & 53.0 defgh & 78.7 abcde & $73.0 \mathrm{hij}$ & $2,041 \mathrm{j}$ \\
\hline 8 & $65.2 \mathrm{bc}$ & $103.8 \mathrm{~g}$ & $3.0 \mathrm{fg}$ & 59.3 abcdef & 78.2 abcdef & 76.3 defg & $2,254 j$ \\
\hline 9 & $66.3 \mathrm{ab}$ & $125.3 \mathrm{f}$ & $3.1 \mathrm{fg}$ & $52.5 \mathrm{efgh}$ & $79.2 \mathrm{abc}$ & 77.5 bcdef & 3,609 bcdefg \\
\hline 10 & $66.0 \mathrm{bc}$ & $123.3 \mathrm{f}$ & $3.9 \mathrm{bc}$ & 59.2 abcdef & $80.7 \mathrm{a}$ & 75.7 efg & 3,286 efg \\
\hline $\mathrm{CK}-60 \times 4$ & $62.2 \mathrm{~d}$ & $163.3 \mathrm{de}$ & $4.6 \mathrm{a}$ & $55.3 \mathrm{cdefgh}$ & $73.5 \mathrm{~g}$ & $71.8 \mathrm{ijk}$ & $2,431 \mathrm{ij}$ \\
\hline 5 & $61.8 \mathrm{de}$ & $124.5 \mathrm{f}$ & $3.1 \mathrm{fg}$ & 54.2 defgh & $76.5 \mathrm{def}$ & $74.3 \mathrm{fghi}$ & $3,100 \mathrm{gh}$ \\
\hline 6 & 60.2 efgh & $181.8 \mathrm{abc}$ & 3.4 def & $49.8 \mathrm{~h}$ & 78.0 bcdef & 77.5 bcdef & 3,607 bcdefg \\
\hline 7 & 61.3 def & $160.5 \mathrm{de}$ & $4.8 \mathrm{a}$ & $50.5 \mathrm{gh}$ & 78.3 abcdef & $71.2 \mathrm{ijk}$ & $2,290 \mathrm{j}$ \\
\hline 8 & $60.8 \mathrm{defg}$ & $134.2 \mathrm{f}$ & $3.2 \mathrm{fg}$ & 55.0 cdefgh & $79.3 \mathrm{abc}$ & 79.5 abcde & 3,355 defg \\
\hline 9 & 61.0 defg & $182.2 \mathrm{abc}$ & $3.2 \mathrm{fg}$ & $52.3 \mathrm{efgh}$ & 79.0 abcd & 77.7 bcdef & $4,217 \mathrm{ab}$ \\
\hline 10 & $59.7 \mathrm{efgh}$ & $187.3 \mathrm{ab}$ & $3.9 \mathrm{bc}$ & $49.7 \mathrm{~h}$ & $79.3 \mathrm{abc}$ & $81.2 \mathrm{abc}$ & 3,851 abcdef \\
\hline Martin $\times 4$ & 59.3 ghij & $172.5 \mathrm{~cd}$ & $4.9 \mathrm{a}$ & $52.7 \mathrm{efgh}$ & $73.8 \mathrm{~g}$ & 74.5 fghi & $2,491 \mathrm{ij}$ \\
\hline 5 & 60.7 defg & $133.2 \mathrm{f}$ & $3.2 \mathrm{fg}$ & 55.8 bcdefgh & 78.0 bodef & $76.2 \mathrm{defg}$ & 3,514 cdefg \\
\hline 6 & $58.3 \mathrm{ijk}$ & $186.0 \mathrm{ab}$ & $3.3 \mathrm{efg}$ & $63.3 \mathrm{ab}$ & 78.5 abode & 79.8 abcde & 3,906 abcde \\
\hline 7 & 59.3 ghij & $162.8 \mathrm{de}$ & $4.9 \mathrm{a}$ & 56.2 bcdefgh & $76.0 \mathrm{f}$ & $71.3 \mathrm{ijk}$ & $1,866 j$ \\
\hline 8 & $58.2 \mathrm{ijkl}$ & $134.2 \mathrm{f}$ & $3.9 \mathrm{bc}$ & 58.3 abcdefg & $79.5 \mathrm{ab}$ & 79.8 abcde & 3,432 defg \\
\hline 9 & $59.8 \mathrm{efgh}$ & $194.0 \mathrm{a}$ & 3.4 def & 59.3 abcdef & $79.2 \mathrm{abc}$ & 80.0 abed & $4,104 \mathrm{abc}$ \\
\hline 10 & $58.8 \mathrm{hij}$ & $193.3 \mathrm{a}$ & $3.8 \mathrm{~cd}$ & 55.2 cdefgh & 77.5 bcde & $81.3 \mathrm{abc}$ & 3,452 defg \\
\hline Redlan $\times 4$ & $58.7 \mathrm{hij}$ & $177.3 \mathrm{bc}$ & $4.8 \mathrm{a}$ & 53.5 defgh & $73.5 \mathrm{~g}$ & $70.0 \mathrm{jk}$ & $2,350 \mathrm{j}$ \\
\hline 5 & $58.3 \mathrm{ijk}$ & $133.2 \mathrm{f}$ & $3.1 \mathrm{fg}$ & 56.7 bcdefgh & 76.8 cdef & 77.2 cdef & $3,229 \mathrm{fg}$ \\
\hline 6 & $56.3 \mathrm{~m}$ & $181.0 \mathrm{abc}$ & $3.2 \mathrm{fg}$ & $60.7 \mathrm{abcd}$ & 78.5 abcde & $80.7 \mathrm{abc}$ & $3,957 \mathrm{abcd}$ \\
\hline 7 & $58.0 \mathrm{jklm}$ & $156.5 \mathrm{e}$ & $4.9 \mathrm{a}$ & 53.8 defgh & 76.8 cdef & 73.0 hij & $2,119 \mathrm{j}$ \\
\hline 8 & $56.8 \mathrm{klm}$ & $127.3 \mathrm{f}$ & $3.3 \mathrm{efg}$ & $62.5 \mathrm{abc}$ & $79.3 \mathrm{ab}$ & $82.2 \mathrm{a}$ & 3,779 abcdef \\
\hline 9 & $56.8 \mathrm{klm}$ & $190.5 \mathrm{a}$ & $3.3 \mathrm{efg}$ & $64.8 \mathrm{a}$ & 78.3 abcdef & $80.8 \mathrm{abc}$ & 4,261 a \\
\hline 10 & $56.5 \mathrm{~lm}$ & $191.7 \mathrm{a}$ & $3.7 \mathrm{cde}$ & 60.2 abcde & 78.0 bcdef & $81.7 \mathrm{ab}$ & 3,795 abcdef \\
\hline
\end{tabular}

1 Values in a column followed by one or more letters in common do not differ significantly at the 5\% level, using Duncan's multiple range test. 
hybrids, which, in turn, were earlier than CK-60 hybrids (table 2). Selfed lines 6,8 , and 10 produced the earliest hybrids. The difference between the earliest hybrid (Redlan $\times 6$ ) and its male parent was -9.7 days (table 3 ). In all cases the differences in earliness between the best hybrids and their male parents were significant.

Height for selfed lines and hybrids ranged from 81.0 to $194.0 \mathrm{~cm}$ (table 1). The types can be grouped into four height categories. In descending order these are: 1) Hybrids with male parents 6,9 , and 10 (181.0 to $194.0 \mathrm{~cm}$ ); 2) hybrids with male parents 4 and 7 (156.5 to 177.3 $\mathrm{cm})$; 3) hybrids with male parents 5 and 8 , and selfed lines $4,6,7,9$, and 10 (123.3 to $134.2 \mathrm{~cm})$; and 4) selfed lines 5 and $8(81.0$ to $103.8 \mathrm{~cm})$. Complementary effects of different height factors in the two parents

TABLE 2.-Mean effects of female and male parents on days to midfower, height, rust rating, heads/plot (H/p), test weight (TW), threshing percentage (TP), and grain yield

$(G Y)$ of $F$, hybrids from crosses of seven sorghum lines with three cytoplasmic malesterile lines (CK-60, Martin, and Redlan), all grown at Isabela, P.R. ${ }^{1}$

\begin{tabular}{lccccccc}
\hline \multicolumn{1}{c}{ Lines or hybrids } & $\begin{array}{c}\text { Days to } \\
\text { midflower }\end{array}$ & Height & $\begin{array}{c}\text { Rust } \\
\text { Rating }\end{array}$ & H/p & TW & TP & GY \\
\hline Seven male parents & 65.6 & 117.1 & 3.5 & 54.6 & 77.7 & 73.7 & 2607 \\
Hybrids having female & & & & & & & \\
$\quad$ parent: & 61.0 & 162.0 & 3.7 & 52.4 & 77.7 & 76.2 & 3264 \\
CK-60 & 59.2 & 168.0 & 3.9 & 57.3 & 77.5 & 77.6 & 3252 \\
Martin & 57.3 & 165.4 & 3.8 & 58.9 & 77.3 & 77.9 & 3356 \\
Redlan & & & & & & & \\
Hybrids having male & & & & & & & \\
parent: & 60.1 & 171.0 & 4.7 & 53.8 & 73.6 & 72.1 & 2424 \\
4 & 60.3 & 130.3 & 3.9 & 55.6 & 77.1 & 75.9 & 3281 \\
5 & 58.3 & 182.9 & 3.3 & 57.9 & 78.3 & 79.3 & 3824 \\
6 & 59.5 & 159.9 & 4.4 & 53.5 & 77.0 & 71.8 & 2091 \\
7 & 58.6 & 131.9 & 3.4 & 58.6 & 79.4 & 80.5 & 3522 \\
8 & 59.2 & 188.9 & 3.3 & 58.8 & 78.8 & 79.5 & 4194 \\
9 & 58.3 & 190.8 & 3.8 & 55.0 & 78.3 & 81.4 & 3699 \\
\hline 10 & & & & & & & \\
\hline
\end{tabular}

${ }^{1}$ No statistical tests were performed on these data.

were apparently responsible for the hybrids in groups 1 and 2 being too tall for harvesting with combines. The tallest $F_{1}$ hybrids were those with female parents Martin and Redlan (table 2). All $\mathrm{F}_{1}$ hybrids were significantly taller than their male parents (table 1).

Rust ratings for selfed lines and $\mathrm{F}_{1}$ hybrids ranged from 2.9 to 4.9 (table 1). The most susceptible genotypes were the hybrids of male parents 4 and 7, and the most resistant, the hybrids of 6, 8, and 9 (table 2). Hybrids of male parent 9 were slightly more resistant than the paternal line selfed, but the differences were not significant (table 3). The rust ratings for hybrids having male parents 5 and 10 were not 
TABLE 3. - Comparison of means for days to midflower, height, rust rating, heads/plot ( $H / p)$, test weight (TW), threshing percentage $(T P)$, and grain yield (GY) of seven sorghum lines and the best $F_{1}$ hybrids from their crosses with male-sterile lines $C K$-60, (A,), Martin $\left(A_{2}\right)$, and Redlan $\left(A_{3}\right)$, all grown at Isabela, P.R.

\begin{tabular}{|c|c|c|c|c|c|c|c|c|c|c|c|c|c|c|}
\hline \multirow[t]{2}{*}{$\begin{array}{c}\text { Male } \\
\text { parent }\end{array}$} & \multicolumn{2}{|c|}{ Days to midflower } & \multicolumn{2}{|c|}{ Height } & \multicolumn{2}{|c|}{ Rust rating } & \multicolumn{2}{|c|}{$\mathrm{H} / \mathrm{p}$} & \multicolumn{2}{|c|}{ TW } & \multicolumn{2}{|c|}{$\mathrm{TP}$} & \multicolumn{2}{|c|}{ GY } \\
\hline & & & & & & & & & $K g$ ! & & & & & ha \\
\hline & $\begin{array}{l}\text { Female } \\
\text { parent }^{1}\end{array}$ & $\mathrm{~d}^{2}$ & $\begin{array}{l}\text { Female } \\
\text { parent }\end{array}$ & $\mathrm{d}$ & $\begin{array}{l}\text { Female } \\
\text { parent }\end{array}$ & $\mathrm{d}$ & $\begin{array}{l}\text { Female } \\
\text { parent }\end{array}$ & $\mathrm{d}$ & $\begin{array}{l}\text { Female } \\
\text { parent }\end{array}$ & $\mathrm{d}$ & $\begin{array}{l}\text { Female } \\
\text { parent }\end{array}$ & $d$ & $\begin{array}{l}\text { Female } \\
\text { parent }\end{array}$ & d \\
\hline 4 & $\mathrm{~A}_{3}$ & $-5.3^{* 3}$ & $\mathrm{~A}_{3}$ & $+45.6^{*}$ & $\mathrm{~A}_{1}$ & $+0.3^{\mathrm{NS}^{4}}$ & $\mathrm{~A}_{1}$ & $+3.3^{\mathrm{NS}}$ & $\mathrm{A}_{2}$ & $+1.5^{\mathrm{NS}}$ & $\mathrm{A}_{2}$ & $+7.5^{*}$ & $\mathrm{~A}_{2}$ & $+540^{\mathrm{NS}}$ \\
\hline 5 & $\mathrm{~A}_{3}$ & $-9.5^{*}$ & $\mathrm{~A}_{2}$ or $\mathrm{A}_{3}$ & $+52.2 *$ & $\mathrm{~A}_{1}$ or $\mathrm{A}_{3}$ & $+.1^{\mathrm{NS}}$ & $\mathrm{A}_{3}$ & $+7.0^{\mathrm{NS}}$ & $\mathrm{A}_{2}$ & $+1.7^{\mathrm{NS}}$ & $\mathrm{A}_{3}$ & $+6.5^{*}$ & $\mathrm{~A}_{2}$ & $+1,414^{*}$ \\
\hline 6 & $\mathrm{~A}_{3}$ & $-9.7^{*}$ & $\mathrm{~A}_{2}$ & $+58.3^{*}$ & $\mathrm{~A}_{3}$ & $+.3^{\mathrm{NS}}$ & $\mathrm{A}_{2}$ & $+7.1^{\mathrm{NS}}$ & $A_{2}$ or $A_{3}$ & $.0^{\mathrm{NS}}$ & $A_{3}$ & $+4.8^{*}$ & $\mathrm{~A}_{3}$ & $+951^{*}$ \\
\hline 7 & $\mathrm{~A}_{3}$ & $-6.7^{*}$ & $\mathrm{~A}_{2}$ & $+35.6^{*}$ & $A_{1}$ & $+.7^{*}$ & $A_{2}$ & $+3.2^{\mathrm{NS}}$ & $A_{1}$ & $-.4^{\mathrm{NS}}$ & $\mathrm{A}_{3}$ & $.0^{\mathrm{NS}}$ & $\mathrm{A}_{1}$ & $+249^{N S}$ \\
\hline 8 & $\mathrm{~A}_{3}$ & $-8.4^{*}$ & $\mathrm{~A}_{1}$ or $\mathrm{A}_{2}$ & $+30.4^{*}$ & $\mathrm{~A}_{1}$ & $+.1^{\mathrm{NS}}$ & $\mathrm{A}_{3}$ & $+3.2^{\mathrm{NS}}$ & $\mathrm{A}_{2}$ & $+1.3^{\mathrm{NS}}$ & $\mathrm{A}_{3}$ & $+5.8 *$ & $\mathrm{~A}_{3}$ & $+1,525^{*}$ \\
\hline 9 & $\mathrm{~A}_{3}$ & $-9.5^{*}$ & $\mathrm{~A}_{2}$ & $+68.7^{*}$ & $A_{1}$ & $+.1^{\mathrm{NS}}$ & $\mathrm{A}_{3}$ & $+12.3^{*}$ & $\mathrm{~A}_{2}$ & $.0^{\mathrm{NS}}$ & $\mathrm{A}_{3}$ & $+3.3^{\mathrm{NS}}$ & $\mathrm{A}_{3}$ & $+652^{*}$ \\
\hline 10 & $\mathrm{~A}_{3}$ & $-9.5^{*}$ & $\mathrm{~A}_{2}$ & $+70.0^{*}$ & $\mathrm{~A}_{3}$ & $-.2^{\mathrm{NS}}$ & $\mathrm{A}_{3}$ & $+1.0^{\mathrm{NS}}$ & $A_{1}$ & $-1.4^{\mathrm{NS}}$ & $\mathrm{A}_{3}$ & $+6.0^{*}$ & $A_{1}$ & $+565^{*}$ \\
\hline
\end{tabular}

${ }^{1}$ Producing best or highest value $\mathrm{F}$, hybrid.

${ }^{2} \mathrm{~d}=$ Mean value for hybrid-mean value for male parent (from table 1 ).

${ }^{3}$ Hybrid significantly different from male parent at the $5 \%$ level, according to Duncan's multiple range test.

${ }^{4}$ Nonsignificant. 
significantly higher than those of their male parents (table 1). Selfed lines or hybrids with ratings above 4 usually sustained considerable loss of leaves.

Heads per plot ranged from 49.7 to 64.8 (table 1). Redlan $\times 9$ had the most H/p, whereas CK-60 $\times 10$ and male parent 5 had the least. Male parent 10 and hybrids Martin $\times 6$, Martin $\times 8$, Martin $\times 9$, Redlan $\times$ 6 , Redlan $\times 8$, Redlan $\times 9$, and Redlan $\times 10$ had mean $\mathrm{H} / \mathrm{p}$ values ranging from 58.3 to 64.8 , with no significant differences among them. The remaining 20 sorghums, with mean values ranging from 49.7 to 56.7 , likewise had no significant differences. Comparison of the highest value $F_{1}$ hybrids with their male parents showed only one significant difference, that between male parent 9 and Redlan $\times 9$ (table 3 ). Hybrids of CK-60 had fewer H/p than did those of Martin or Redlan (table 2). Hybrids of male parents 4 and 7 produced the fewest $\mathrm{H} / \mathrm{p}$, whereas hybrids of 6,8 , and 9 produced the most.

Line $10 \mathrm{had}$ the highest TW, $80.7 \mathrm{~kg} / \mathrm{ha}$ (table 1). Male-parent lines 6,8 , and 9 and their $\mathrm{F}_{1}$ hybrids all had lower, very similar TW's with no significant differences among them. The TW was significantly higher for line 10 than for its $\mathrm{F}_{1}$ hybrids Martin $\times 10$ and Redlan $\times 10$, but the difference between line 10 and CK- $60 \times 10$ was not significant. Line 4 and its $F_{1}$ hybrids had the lowest TW's, ranging from 72.3 to $73.8 \mathrm{~kg} / \mathrm{hl}$. The differences between the best $\mathrm{F}_{1}$ hybrids and their male parents (in most cases, favoring the male parent) were nonsignificant (table 3).

The TP's for selfed lines and hybrids ranged from 67.0 to 82.2 (table 1). Redlan $\times 8$ had the highest TP, followed in descending order by Redlan $\times 10$, Martin $\times 10$, CK $-60 \times 10$, Redlan $\times 9$, Redlan $\times 6$, Martin $\times 9$, Martin $\times 6$, Martin $\times 8$, and CK $-60 \times 8$. These 10 types all had statistically similar TP's ranging from 79.5 to 82.2 . The 10 lines or hybrids with the lowest TP's were (in ascending order) 4 , Redlan $\times 4,5$, CK-60 × 7, Martin $\times 7$, Redlan $\times 7$ and 7, CK-60 $\times 4$, Martin $\times 4$, and $\mathrm{CK}-60 \times 5$. Hybrids of male parents $6,8,9$, and 10 had the highest TP's, whereas hybrids of 4,5 , and 7 had the lowest (table 2). The greatest difference between a male parent and its best $F_{1}$ hybrid was that between 4 and Martin $\times 4$ (table 3). With all male parents except 7 , the best $F_{1}$ hybrids had significantly higher TP's.

The GY's for all sorghums ranged from 1,866 to $4,261 \mathrm{~kg} /$ ha (table 1 ). The three top hybrids were Redlan $\times 9$, CK $-60 \times 9$, and Martin $\times 9$, with 4,261, 4,217, and 4,104 kg/ha, respectively. These were followed, in descending order, by Redlan $\times 6$, Martin $\times 6$, CK $-60 \times 10$, Redlan $\times$ 8 , Redlan $\times 10$, male parent 9 , and CK $60 \times 6$, with yields ranging from 3,607 to $3,957 \mathrm{~kg} / \mathrm{ha}$. There were no significant differences among these 10 sorghums, but their GY's were significantly higher than those of most of the remaining parents and $\mathrm{F}_{1}$ hybrids. The 10 lowest grain 
yields (ranging from 1,866 to $2,491 \mathrm{~kg} / \mathrm{ha}$ ) were, in ascending order, those of Martin × 7, 4, 7, 5, Redlan × 4, and Redlan $\times 7,8$, CK- $60 \times 7$, CK-60 $\times 4$, and 6 . There were no significant differences among these 10 sorghums. Male parents 9 and 6 (and, to a lesser degree, 10) clearly showed superior combining ability, but male parents 4 and 7 appeared to lack this ability (table 2). Figure 1 shows the yield relationship between parents and $F_{1}$ hybrids. The hybrids having a common male parent performed very similarly. These results suggest that, in an evaluation of lines, one hybrid or test cross is enough.

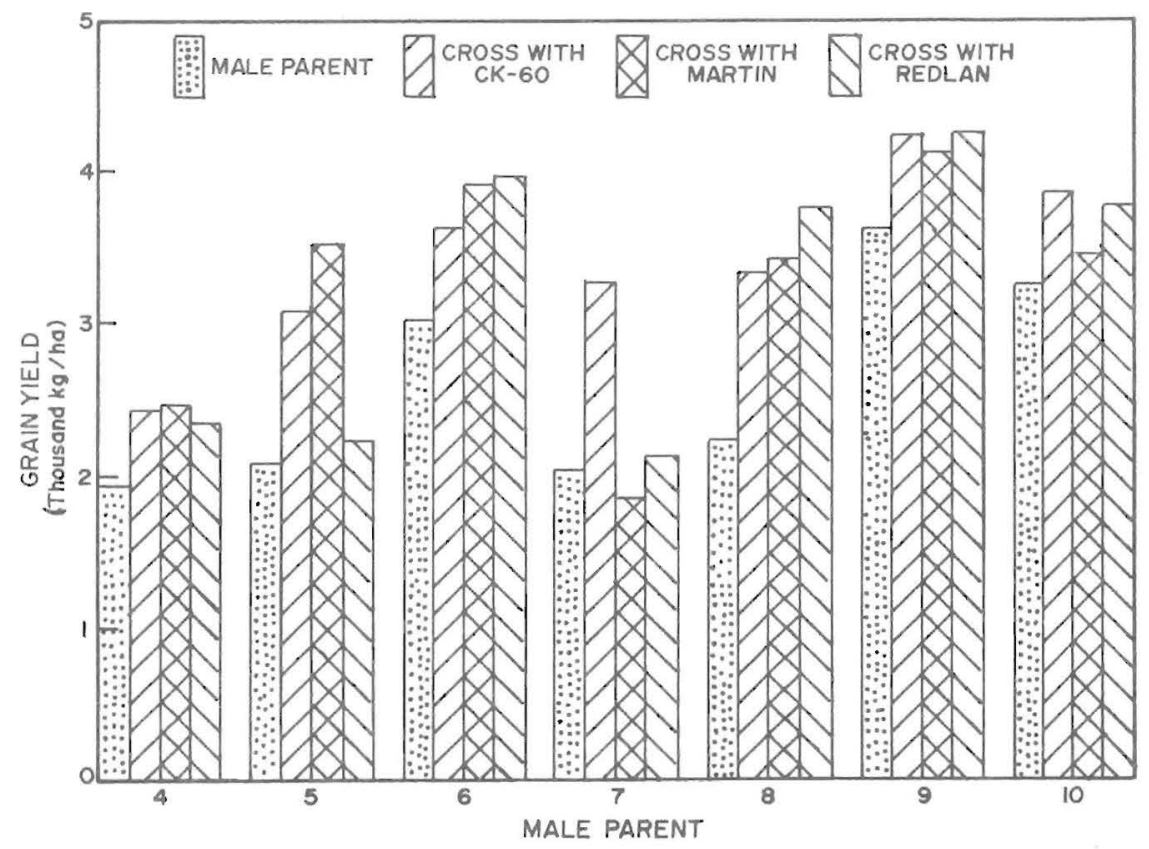

FIG. 1. - Relationship between grain yield of seven sorghum male-parent lines and grain yield of their $F_{1}$ hybrids from crosses with male-sterile lines CK-60, Martin, and Redlan, all grown at Isabela, P.R.

Of the selfed lines, 10 and 9 had the highest GY's, 3,286 and 3,609 $\mathrm{kg} / \mathrm{ha}$, respectively (table 1). These means were significantly higher than those of all other selfed lines except 6. A similar pattern of GY in the same lines was observed in a previous study by Sotomayor-Ríos and Miller at Isabela, P.R. (4). The GY's of CK-60 $\times 4$ and CK-60 $\times 7$ were not significantly different from those of their male parents; these findings suggest that male parents 4 and 7 lack combining ability, although heterosis was 24.6 and $17.4 \%$ respectively, in the two $\mathrm{F}_{1}$ hybrids. Martin $\times 5$ and Redlan $\times 8$ had GY increases of about 67.3 
and $67.4 \%$ over their respective male parents; the combining ability of male parents 5 and 8 was clearly superior to that of the other selfed lines.

The research on grain sorghum in Puerto Rico is very limited. Wahab et al. (6) and Fox (2) have reported yields in Puerto Rico that vary from 2,600 to $4,300 \mathrm{~kg} / \mathrm{ha}$. In our study, GY's of over 4,000 kg/ha are reported for some $F_{1}$ hybrids, although only about $60 \mathrm{~kg} \mathrm{~N} /$ ha was applied. Even higher yields can be expected under more intensive management.

When the three cytoplasmic male-sterile lines, CK-60, Martin, and Redlan, were crossed to the seven male parents, the hybrids sometimes performed differently in the various traits studied. Calculation of the mean effect of each female parent (table 2) showed that Redlan produced the earliest hybrids; Martin, the tallest, and Redlan, the largest number of heads/plot $(\mathrm{H} / \mathrm{p})$. The mean effects of the three female parents on rust rating and test weight (TW) were very similar. In terms of grain yield (GY) Martin and Redlan produced the best hybrids, especially in crosses with male parents 5 and 8; the highest heterosis was observed in these hybrids.

The results of this study indicate that the Sorghum Conversion Program (SCP) can provide excellent sorghum lines, with desirable morphological properties and good potential for yield, which could be valuable in a further improvement program. This study shows the value of the SCP for sorghum production in the tropics, although it was designed for breeding improvement for temperate zones. The hybrids obtained from crosses with any of the three well-known cytoplasmic male-sterile lines tested performed highly satisfactorily in the main traits studied, especially total grain yield per hectare.

\section{RESUMEN}

Siete líneas de sorgo de grano (Sorghum bicolor (L.) Moench) seleccionadas del Programa de Conversión, y sus híbridos $\left(\mathrm{F}_{1}\right)$ se evaluaron en la finca experimental del Instituto Mayagüezano de Agricultura Tropical. Tres líneas androestériles, CK-60, Martin y Redlan, se utilizaron como progenitores femeninos.

Los días transcurridos hasta que la mitad de las plantas florecieran fluctuaron entre 56.3 y 67.8. En general, las líneas masculinas (autofecundas) fueron mas tardías que sus respectivos híbridos. Los híbridos de Redlan fueron más precoces que los de Martin y éstos aún más tempranos que los de CK-60. La diferencia entre el híbrido más temprano y su correspondiente línea masculina fue de -9.7 días. Se observaron cuatro grupos con respecto a la altura de las plantas; su fluctuación fue de 81 a $194 \mathrm{~cm}$. Se atribuyó al efecto complementario de factores de altura el que los híbridos de los grupos 1 y $2(181.0$ a 194.0 y 156.5 a $177.3 \mathrm{~cm})$ fuesen demasiado altos para recolectarse con. máquinas cosechadoras (combinas). La incidencia de la roya causada por Puccinia purpurea fluctuó entre 2.9 y 4.9. Los híbridos Martin $\times 4$, Martin $\times 7$ y Redlan $\times 7$ fueron los más susceptibles al ataque de roya.

El porcentaje de rendimiento para las líneas masculinas e híbridos fiuctuó entre 67.0 y 82.2 . El híbrido Redlan $\times 8$ obtuvo el más alto.

La producción de grano fluctuó entre 1,886 a 4,261 kg/ha. Los tres híbridos superiores fueron Redlan $\times 9$, CK-60 × 9 y Martin $\times 9$ con $4,261,4,217$, y $4,104 \mathrm{~kg} / \mathrm{ha}$, respectivamente. Las líneas 9 y 6 mostraron tener la mejor aptitud combinatoria. De 
las líneas masculinas las 10 y 9 fueron las mejores productoras con 3,286 y 3,609 $\mathrm{kg} / \mathrm{ha}$, respectivamente. Los híbridos Martin $\times 5$ y Redlan $\times 8$ mostraron tener una superioridad en producción de grano de 67.3 y $67.4 \%$ sobre las respectivas líneas masculinas.

Se concluye de este estudio que, el Programa de Conversión de Sorgo es capaz de proveer líneas de excelente valor, las cuales podrían utilizarse directamente tanto para el consumo como alimento de animales o en un programa de mejoramiento. Los híbridos $\left(\mathrm{F}_{1}\right)$ obtenidos utilizando cualquiera de las tres lineas androestériles mostraron poseer caracteres muy deseables, especialmente una magnífica producción de grano por hectárea.

\section{LITERATURE CITED}

1. Eberhart, S. A., 1967. Progress report on the Sorghum Conversion Program in Puerto Rico and plans for the future, J. Paper No. J-6772, Iowa, Agric. Home Econ. Exp. Stn., Ames, Iowa.

2. Fox, R. H., Talleyrand, H., and Bouldin, D. R., 1974, Nitrogen fertilization of corn and sorghum grown in Oxisols and Ultisols in Puerto Rico, Agron. J. 66: 534-40.

3. Schertz, K. F., 1975. Use and potentials of the Sorghum Conversion Program to reduce genetic vulnerability in sorghum, Proc. Int. Sorghum Workshop, Univ. P.R., Jan. 7-11.

4. Sotomayor-Ríos, A., and Miller, F. R., 1977. Performance of ten grain sorghum lines from the Conversion Program, J. Agric. Univ. P.R. 61(4): 443-50.

5. Stephens, J. C., Miller, F. R., and Rosenow, D. T., 1967. Conversion of alien sorghums to early combine genotypes, Crop Sci. 7: 396 .

6. Wahab, A., Talleyrand, H., and Lugo-López, M. A., 1976. Rooting depth, growth and yield of sorghum as affected by soil water availability in an Ultisol and an Oxisol, J. Agric. Univ. P.R. 60(3):329-35. 